\title{
Regulatory potential of parasitoids over Aphis gossypii Glover, 1877 populations (Hemiptera: Aphididae) under semi- arid laboratory conditions
}

\author{
Raouf Bensaad ${ }^{1,2}$, Yannick Outreman ${ }^{3}$, Anne le Ralec ${ }^{3}$, Yamina Guenaoui ${ }^{1}$ \\ 1 Département des Sciences Agronomiques, Université Abdelhamid Ibn Badis, Mostaganem, 27000, Algérie. \\ 2 Département des Sciences Agronomiques et Vétérinaires, Université Ziane Achour Djelfa, 17000, Algérie. \\ 3 IGEPP, Agrocampus Ouest, INRA, Université de Rennes 1, Université Bretagne-Loire, 35000 Rennes, France.
}

\author{
Correspondence \\ R. Bensaad \\ E-mail: r.bensaad@univ-djelfa.dz
}

Received: 13 June 2019

Accepted: 9 December 2019

Published on-line: 18 December 2019

\section{Resumen}

Potencial regulador de parasitoides sobre poblaciones de Aphis gossypii Glover, 1877 (Hemiptera: Aphididae) en laboratorio, bajo condiciones semiáridas

Este estudio tiene como objetivo evaluar el potencial regulador de Lysiphlebus testaceipes y Aphidius matricariae sobre Aphis gossypii en condiciones de laboratorio semiáridas. Nuestros resultados mostraron que la longevidad de las hembras de $L$. testaceipes fue significativamente menor que la de $A$. matricariae. El porcentaje diario de momificación fue más importante para $L$. testaceipes que para A. matricariae y disminuyó con la edad de los parasitoides. En general, las tasas de momificación y de emergencia fueron más altas en $L$. testaceipes. La descendencia de $A$. matricariae se desarrolló en menos tiempo que la de $L$. testaceipes. La proporción sexual no varió respecto a las especies parasitoides. Con nuestros resultados, $L$. testaceipes fue más efectivo para el control biológico de $A$. gossypii en patata en agro-ecosistemas semiáridos.

Palabras clave: Plaga de pulgones; Control biológico; Cultivo de patata; Condiciones climáticas; Lysiphlebus testaceipes; Aphidius matricariae.

\begin{abstract}
This study aims to evaluate the regulatory potential of Lysiphlebus testaceipes and Aphidius matricariae over Aphis gossypii in semiarid laboratory conditions. Our results showed that the longevity of L. testaceipes females was significantly lower than $A$. matricariae ones. The daily mummification rate of aphid was more important for L. testaceipes than for $A$. matricariae and declined with parasitoids age. Overall, both the mummification rates and the emergence rates were the highest in $L$. testaceipes. A. matricariae offspring developed in a shorter time compared to $L$. testaceipes ones. The overall sex ratio did not vary according to parasitoid species. From our results $L$. testaceipes was more effective for the biological control of $A$. gossypii on potato in the semi-arid agro-ecosystems.
\end{abstract}

Key words: Aphid pests; Biological control; Potato fields; Climatic conditions; Lysiphlebus testaceipes; Aphidius matricariae. 


\section{Introduction}

Aphids are one of the major insect crop pests (Dedryver, et al. 2010). Their damage can cause serious yield losses, mainly through virus transmission (Woodford \& Gordon 2008 et al. 2013). In order to protect their crops, farmers frequently use insecticides to control aphid population density. By the agricultural practices, both environment and public health are highly threatened by the spreading of chemicals in ecosystems and agricultural products, as well as the emergence of resistant strains of insect pests that inevitably lead to increased chemical treatments (Slininger et al. 2003). Biological control of aphids by using natural enemies such as insect parasitoids is one alternative to chemical control and has been the subject of many studies world wide under variable climatic conditions (Powell \& Pell 2007). The regulatory potential measure of natural enemies may be conducted in the climatic conditions of the targeted crops.

In Algeria, the potato (Solanum tuberosum L.) is ranked as first in the Algerian population's diet compared to other vegetable crops. In 2017, more than 470.000 tons of potatoes were produced on an area of 149.000 ha (MADRP 2018). From 2000s, potatoes were intensively cultivated in the region of Djelfa in the centre of Algeria (MADRP 2018). In this steppe region, the potato is produced at altitudes that can exceed $1200 \mathrm{~m}$. The Djelfa region is characterized by a semi-arid to arid climate where relative humidity $(\mathrm{RH})$ is low with a dry and hot summer season that lasts about 6 months. However, the winter (October - April) is rainy and cold (Le Houerou, et al. 1977). From 2004 to 2013, the monthly averages temperatures were $\mathrm{Min}=0.4 \mathrm{C}^{\circ}$ and $\mathrm{Max}=34.6 \mathrm{C}^{\circ}$, and relative humidity varied between $34.7 \%$ in July and $81.5 \%$ in December with rainfall of $14.11 \mathrm{~mm}$ to $35.01 \mathrm{~mm}$ (annual average $312.78 \mathrm{~mm}$ ).

In the Djelfa region, the potato crops were attacked by several species of aphids (Hemiptera: Aphididae) such as Aulacorthum solani Kaltenbach, 1843, Macrosiphum euphorbiae Thomas, 1878, Myzus persicae Sulzer, 1776, Aphis fabae Scopoli, 1763 and Aphis gossypii Glover, 1877. Most of these species are crop pests and also transmit viral diseases to potatoes. Aphis gossypii is a cosmopolitan and extremely polyphagous species and a widely distributed pest in tropical, subtropical and temperate regions (Leclant \&
Deguine 1994, Fuller et al.1999). It is the most abundant aphid species on potatoes in the Djefla region (Yahiaoui 2014, Medri 2014). Biological control possibilities of this aphid would be a good regulative measure for controlling its populations. Two parasitoid species, Lysiphlebus testaceipes (Cresson 1880) and Aphidius matricariae (Haliday 1834) (Hymenoptera: Braconidae) were identified as parasitoids on $A$. gossypii in many reports (Carnevale et al.2003; Bueno et al. 2006, Talebi et al. 2006, Zamani, et al. 2007, Laamari et al. 2011, Zamani et al. 2012, Nazari et al. 2012, Mitrovic et al. 2013, Sellami et al. 2013, Chaouche \& Laamari 2015). Several studies have shown their effectiveness on other aphid species (Costa \& Stary 1988, Rodrigues \& Bueno 2001, Carnevale et al. 2003, Stary et al. 2004, Sampaio et al.2006, Zamani, et al. 2006, Adabi et al. 2 010). This paper is the first work to consider the semi-arid conditions of potato crops, aimed at assessing the two parasitoid species as biological control agents against $A$. gossypii by studying their parasitic capacity as well as their life-history traits. From this study, we expect to evaluate their incidence on the aphid populations by considering these peculiar climatic conditions.

\section{Materials and methods}

\section{Aphids and parasitoids}

Since the parasitism capacity of parasitoids may vary according to aphid genotypes (Ferrari et al. 2001), aphids were collected at different sites and in different periods in the region of Djelfa in order to obtain genetic variation within experimental aphid populations. A. gossypii collected in Djelfa were sampled in two distinct areas $119 \mathrm{kms}$ apart: 550 individuals in Dar Chioukh and 365 in Ain Oussara. Aphids were kept to identify their parasitic status and if healthy (i.e. no aphid mummification due to parasitoid immature development), they were mixed and bred on potato plants (Désirée variety) planted in pots $(20 \mathrm{~cm}$ in diameter and $30 \mathrm{~cm}$ in height) and placed in breeding cages $(80 \times 40 \times 40 \mathrm{~cm})$. For the parasitism experiments, only third-instar aphid nymphs were used because this is the preferred instar for oviposition by the parasitoid species (Outreman et al. 2001a, 2001b, Rodrigues 2001, Colinet et al. 2005, Bueno et al. 2006, Zamani et al. 2012, Tepa-Yotto et al. 2013). 
The considered parasitoid species in this study were $L$. testaceipes and A. matricariae, obtained from A. gossypii mummies (i.e. dead aphids enclosed an immature parasitoid) and adult parasitoids collected between mid-April and early July in several potato fields in the same areas as the aphids (Dar Chioukh and Ain Oussara) in Djelfa region (at different altitudes between 700 and 1,100 maslm). The number of all emerging parasitoids from collected mummies was 48 adults of L. testaceipes and 32 of $A$. matricariae. The parasitoid wasps of each species were separately reared on potato plants over $A$. gossypii. This parasitoid sampling design insured genetic variation within the experimental parasitoid populations.

All insects were maintained in climate rooms under similar semi-arid conditions at $25 \pm 1{ }^{\circ} \mathrm{C}, 34$ $\pm 6 \% \mathrm{RH}$ and $16 \mathrm{~L}: 8 \mathrm{D}$ photoperiod. Under these conditions, aphids reproduced by parthenogenesis.

\section{Experiments}

In order to reproduce aphids for establishing experiments, several wingless $A$. gossypii adults were deposited on fresh potato leaves placed into a Petri dish ( $9 \mathrm{~cm}$ in diameter) covered with a fine mesh to ensure aeration. After twenty-four hours, adult aphids were removed and the young nymphs were isolated in groups of 30 individuals in Petri dishes containing potato leaves which were renewed daily. Once nymphs reached the third-instar stage, they were transferred on fresh potato leaves into a tube (height $5 \mathrm{~cm}$; diameter: $3 \mathrm{~cm}$ ) covered by tulle according to the method described by Rodrigues \& Bueno (2001). These aphids were then exposed to parasitoid attacks by introducing a parasitic wasp into the tube for $24 \mathrm{~h}$.

At the beginning of the experiments, parasitoid females were 1-day old, mated and kept with a solution of water and honey. Until its death, a single parasitoid female was daily transferred to a new tube containing 30 healthy third-instar aphid nymphs and fresh potato leaves. After each day, the 30 aphid individuals exposed to a parasitoid female were placed into a Petri dish $(9 \mathrm{~cm}$ in diameter) on a potato leaf and their parasitism status followed up to the parasitoid's offspring emergence. The date of emergence of the offspring and their sex were noted.

From these experiments, we measured: the parasitoid female longevity (from the beginning of the test until the wasp's death); its daily parasitism rate (i.e., rate of mummified aphids among the 30 aphids exposed to a parasitoid female during a given day); the rate of parasitoid emergence from mummified aphids (i.e. number of parasitoids that emerged from the mummified aphids from a given day); the development time of emerging parasitoids (i.e., duration from the oviposition to the parasitoid emergence) and the sex of the emerging parasitoids. From all these data, the total number of aphids killed per parasitoid female was calculated by cumulating the number of mummified aphids. The total number of parasitoid offspring produced by one given female parasitoid was calculated by cumulating the number of offspring emerging from aphids.

For each parasitoid species, five adult females were tested. From these experiments, the parasitism status of 3,030 aphid individuals was observed, and both development time and sex of 1,159 parasitoid offspring were noted. Experimental tests were conducted under the semi-arid laboratory conditions at $25 \pm 1{ }^{\circ} \mathrm{C}, 34 \pm 6 \% \mathrm{RH}$, and 16L:8D photoperiod.

\section{Statistical analysis}

The effect of parasitoid species o parasitoid female longevity was tested by using a Generalized Linear Model (GLM) considering a Gamma family and inverse link function. We analysed the effects of the parasitoid female's age, the parasitoid species and their interaction on both the daily mummification rate and the daily emergence rate from aphid mummies by using Generalized Linear Mixed Model (hereafter GLMM) considering a Binomial family and logit link function. As several aphids were exposed to the same parasitoid female (i.e., data dependency), the female identity was included as a random factor in all these Binomial GLMMs. Concerning the offspring produced by parasitoid females, the effects of the parasitoid female's age, the parasitoid species and their interaction on both the development time and sex of their offspring were analysed using Gamma and Binomial GLMMs respectively. As some offspring were produced by the same parasitoid female (i.e., data dependency), the female identity was included as a random factor in these GLMMs. Finally, the effect of parasitoid species on both the total number of aphids killed per parasitoid female and the total number of offspring produced per parasitoid female were analysed against the parasitoid species by using general Linear Models 
(LM), after validation of the Normal distribution of the models' residuals.

GLMMs, GLMs and LMs were computed using the lme4 R-package (Bates et al. 2015). Over dispersion in Binomial GLMMs was tested using the blmeco R-package that computed the estimated scale in a binomial mixed model (Korner-Nievergeltetal 2015). All analyses were computed using R v. 3.4.2 (R Development Core Team 2017).

\section{Results}

While attacking the aphid A. gossypii continuously, the two parasitoid species differed in their life span. The average longevity of $L$. testaceipes adult females was significantly shorter than that of A. matricariae (Fig. $1 ; \mathrm{X}^{2}=68.31, \mathrm{df}=1, \mathrm{p}<0.001$ ). During their lifetime, the parasitism activity of the parasitic wasps strongly varied according to their age (Fig. 2a). Indeed, the daily rates of mummification of A. gossypii declined with the experimental day $\left(\mathrm{X}^{2}=459.66, \mathrm{df}=1, \mathrm{p}<0.001\right)$ and were greater when aphids were attacked by $L$. testaceipes $\left(\mathrm{X}^{2}=4.70, \mathrm{df}=1, \mathrm{p}=0.03\right)$. The relationship between the female age and the daily mummification rates for both parasitoid species was similar $\left(\mathrm{X}^{2}=0.82, \mathrm{df}=1, \mathrm{p}=0.364\right)$. Overall, the mummification rate was significantly higher in L. testaceipes compared with A. matricariae (Fig. 2b). The rate of parasitoid emergence from the $A$. gossypii mummies differed according to the parasitoid species. Whatever the females' age (Fig. 3a; $\mathrm{X}^{2}=2.29, \mathrm{df}=1, \mathrm{p}=0.129$ ), emergence rate was higher for $L$. testaceipes $\left(\mathrm{X}^{2}=104.21, \mathrm{df}=1\right.$, $\mathrm{p}<0.001)$. Overall, the emergence rate was $80.61 \%$ for $L$. testaceipes and $55.42 \%$ for $\mathrm{A}$. $\mathrm{ma}$ tricariae (Fig. 3b), suggesting the highest parasitism success in L. testaceipes.

By using A. gossypii as host, the development time of the parasitoid immatures, from egg deposition by the female to offspring emergence, varied according to the parasitoid species. Whatever the female adults' age (Fig. 4a; $\mathrm{X}^{2}=1.36, \mathrm{df}=1$, $\mathrm{p}=0.242$ ), $A$. matricariae offspring developed in a shorter time compared to those of $L$. testaceipes ones (Fig. $4 \mathrm{~b} ; \mathrm{X}^{2}=9.44, \mathrm{df}=1, \mathrm{p}<0.005$ ). The overall sex ratio in parasitoid populations emerging from $A$. gossypii did not vary with parasitoid species: in both species, sex ratio was female-bias (A. matricariae $=0.77 \pm 0.15 ;$ L. testaceipes $=0.71$ $\left.\pm 0.13 ; \mathrm{X}^{2}=0.52, \mathrm{df}=1 ; \mathrm{p}=0.468\right)$.

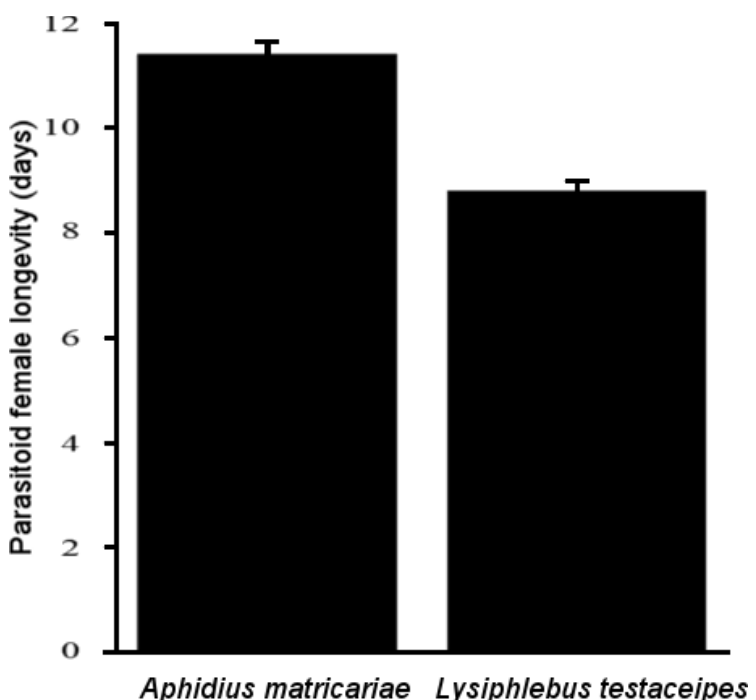

Figura 1. La longevidad de la hembra adulta parasitoide (días) dependiendo de la especie parasitoide mientras están expuestas a individuos huéspedes de Aphis gossypii (media \pm error estándar).

Figure 1. The parasitoid adult female longevity ( days) depending on the parasitoid species while exposed to Aphis gossypii host individuals (Mean \pm standard error).

By considering all aphids that mummified after parasitoid exposure, our results showed that the total number of aphids killed by parasitic wasps was higher when aphids were exposed to $L$. testaceipes females compared to A. matricariae (Fig. 5a; $\mathrm{F}_{1,7}=9.62, \mathrm{p}<0.05$ ). By considering all parasitoid offspring that emerged from the mummified $A$. gossypii aphids, our results showed that the total number of parasitoid individuals produced in our experimental conditions was also high in L. testaceipes (Fig. 5b; $\mathrm{F}_{1,7}=173.27$, $\mathrm{p}$ $<0.001)$.

\section{Discussion}

The present paper aims at comparing the regulatory potential of two aphid parasitoids against the aphid A. gossypii on potatoes in semi-arid laboratory conditions. Our results showed that L. testaceipes performs better on this aphid than A. matricariae and would therefore be a candidate for biological control in this context. Both species succeed in parasitizing A. gossypii, but $L$. testaceipes parasitize more aphids and produce more progeny despite its shorter longevity.

The high longevity observed here for A. matricariae is congruent with the study of Zamani et al. (2007), who reported a longevity of 11.9 days on $A$. gossypii on cucumber $\left(25 \pm 1{ }^{\circ} \mathrm{C}, 65 \pm 5 \%\right.$ RH). In the same way, Carnevale et al. (2003) and Soglia et al. (2006), observed a short life duration 
(a)

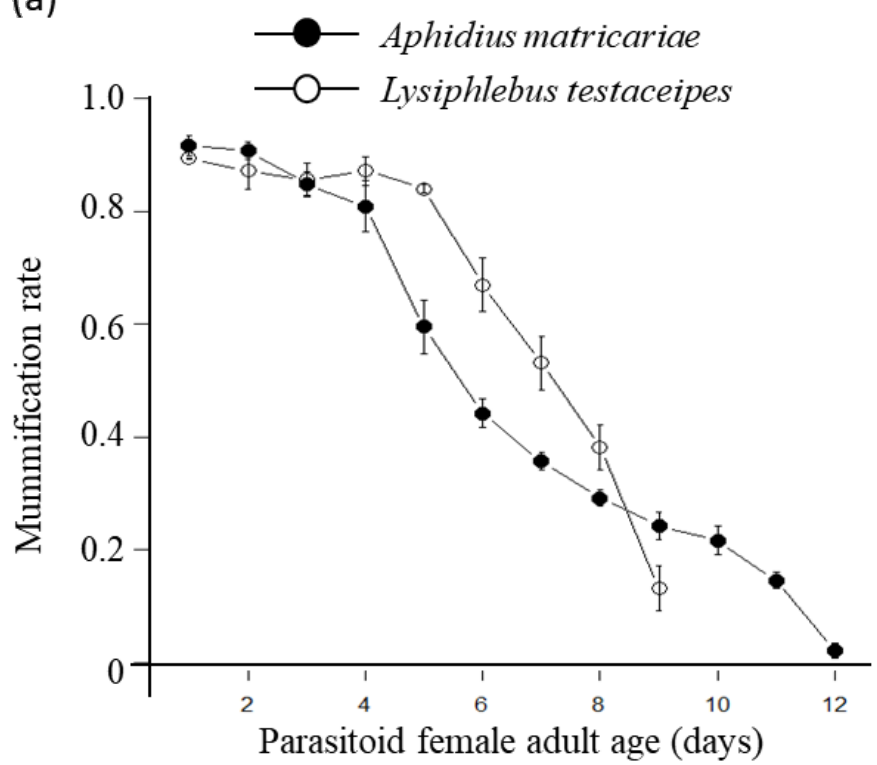

(b)

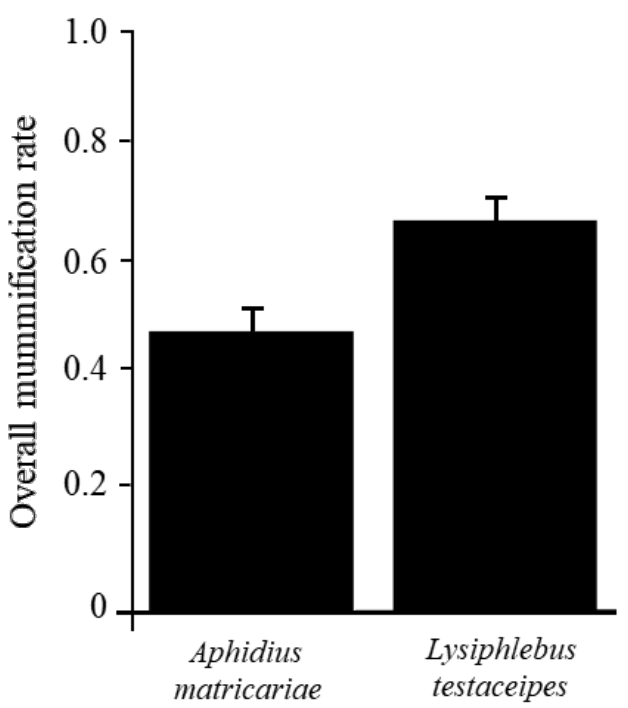

Figura 2. Tasa de momificación de áfidos. a: Edad adulta parasitoide femenina y la especie parasitoide. b: Tasa de momificación general dependiendo de la especie parasitoide.

Figure 2. Rate of aphid mummification. a: Parasitoid female adult age and the parasitoid species. b: Overall mummification rate depending on the parasitoid species.
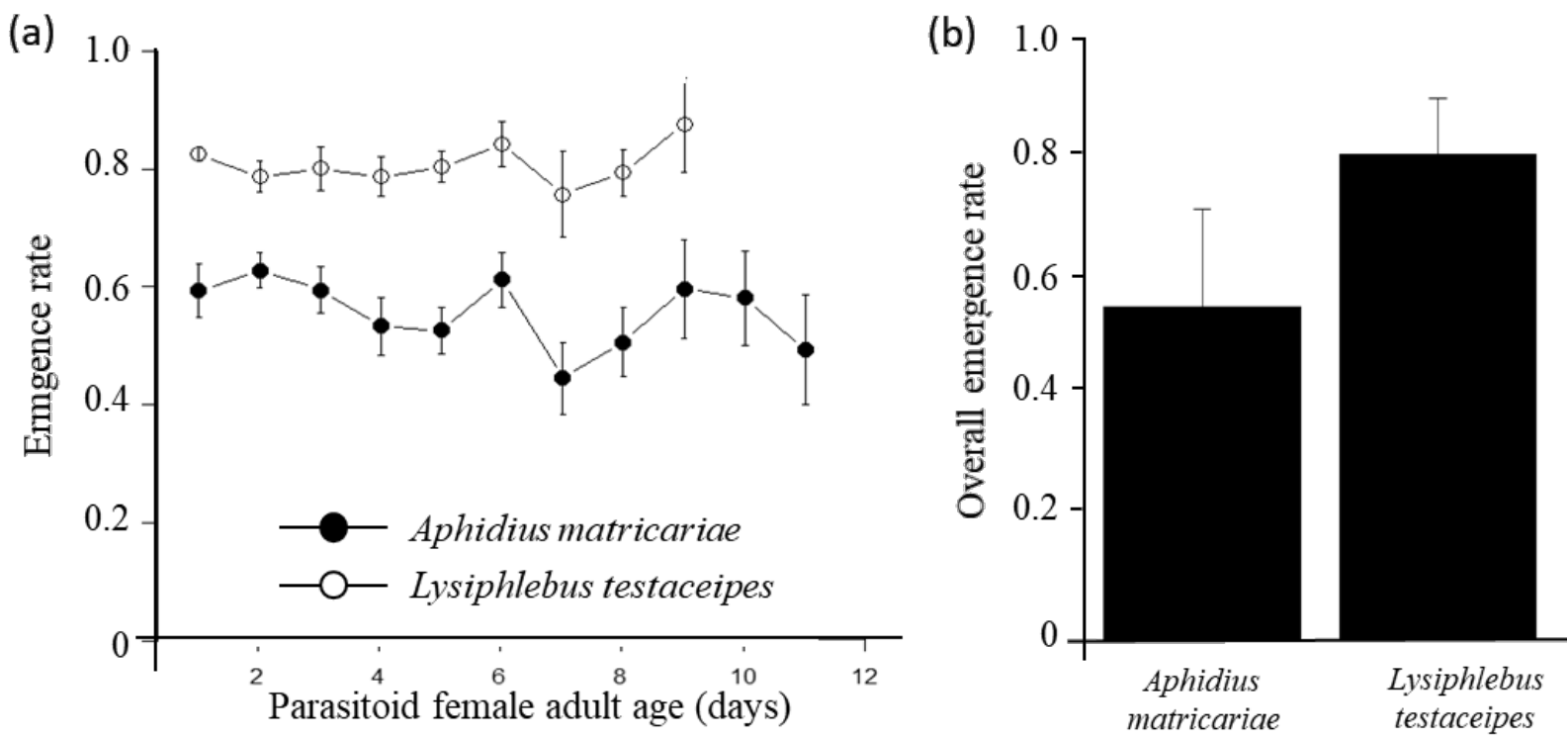

Figura 3: Tasa de aparición inmadura de parasitoides de momias de pulgones. a: Edad adulta parasitoide femenina por especie parasitoide. b: Tasa de emergencia general de las momias de $A$. gossypii dependiendo de la especie parasitoide.

Figure 3. Rate of parasitoid immature emergence from aphid mummies. a: Parasitoid female adult age in each parasitoid species. b: Overall emergence rate from $A$. gossypii mummies depending on the parasitoid species.

for $L$. testaceipes, respectively 5.5 days $(25 \pm 1$ $\left.{ }^{\circ} \mathrm{C}, 70 \pm 10 \% \mathrm{RH}\right)$ and up to 4.2 days.

The method used in this study allows the full expression of the parasitoid's reproductive potential by providing females with a large number of healthy aphids until their death. During the first four days of their life, females of both species successfully parasitized around $90 \%$ of these aphids, after which the mummification rate of aphids exposed to A. matricariae became lower than for L. testaceipes. These higher daily successes, probably related to a high fecundity (Silva et al. 2008) compensate for the lower longevity of the latter species and explain the overall better parasitism rate obtained with $L$. testaceipes.

We identified a second trait that it could be of great importance for the efficiency of the parasi- 

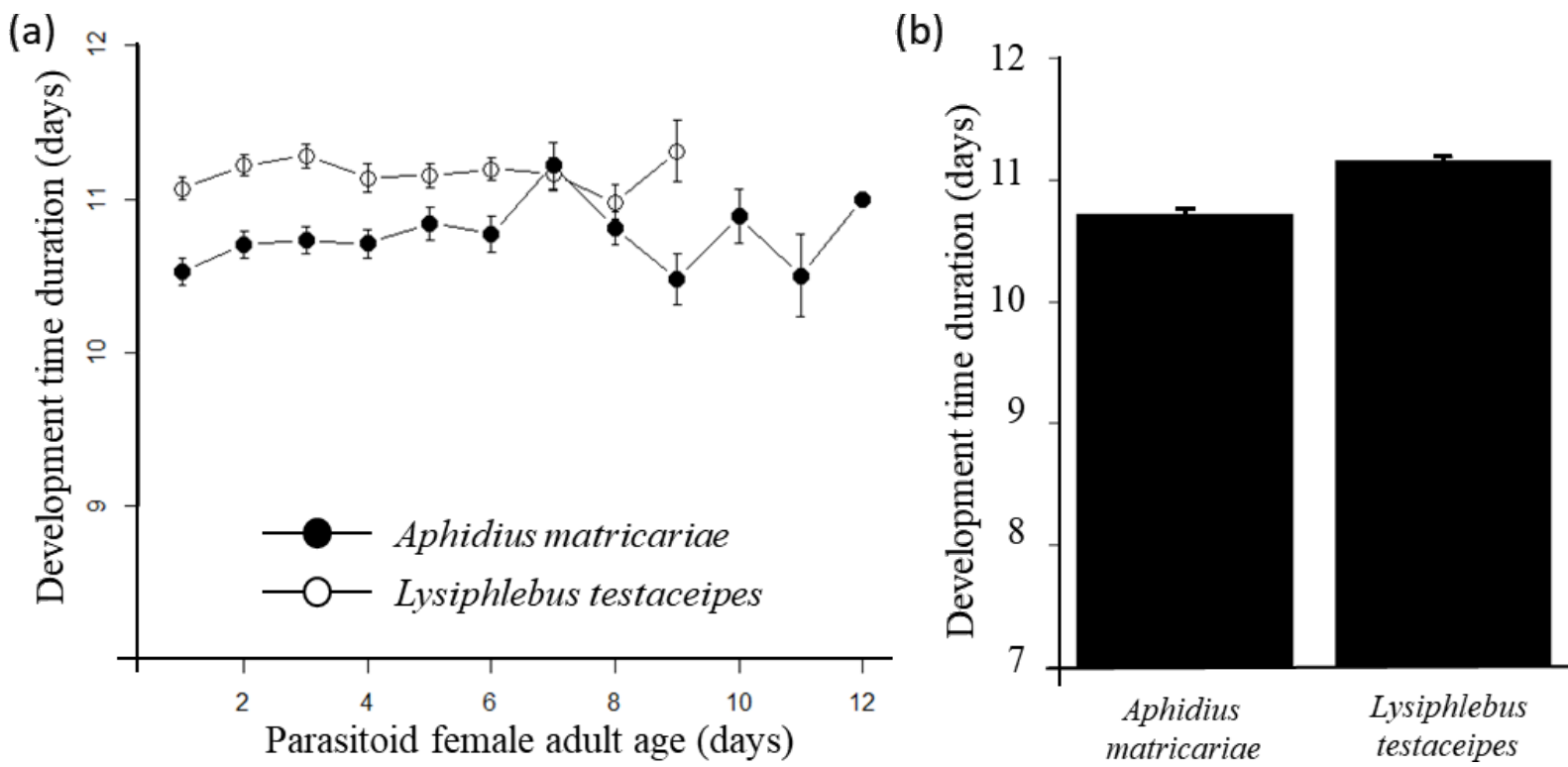

Figura 4. Duración del desarrollo de la descendencia parasitoide que emerge de las momias de A. gossypii. a: Edad adulta parasitoide femenina por especie parasitoide. b: Duración total del desarrollo de las momias de A. gossypii dependiendo de la especie parasitoide.

Figure 4. The development time duration of parasitoid offspring emerging from A. gossypii mummies. a: Parasitoid female adult age in each parasitoid species. b: The overall development time duration from $A$. gossypii mummies depending on the parasitoid species.
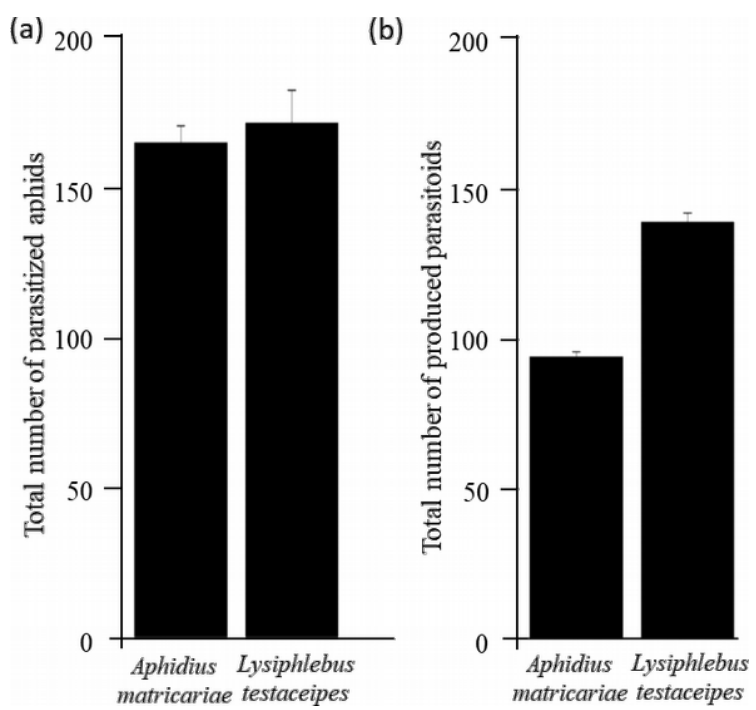

Figura 5. a: Número total de pulgones muertos por avispas parásitas dependiendo de la especie parasitoide. b: Número total de descendientes parasitoides producidos por las avispas parásitas dependiendo de la especie parasitoide.

Figure 5. a: Total number of killed aphids by parasitic wasps depending on the parasitoid species. b: Total number of parasitoid offspring produced by the parasitic wasps depending on the parasitoid species.

toids to regulate aphid populations. In our experimental conditions, almost half of the mummies obtained from $A$. matricariae did not give an adult. This could perhaps be related to the climate conditions in which the experiment was done, in order to reproduce the semi-arid climate of the studied area. For example, Domo \& Tylianakis (2013) showed a negative effect of the combina- tion of high temperatures and drought on the emergence rate of another Aphidiinae parasitoid, Diaeretiella rapae (McIntosh, 1855). In the study of Zamani et al. (2007), an emerging rate of $88,1 \%$ was obtained on $A$. matricariae at a temperature of $25{ }^{\circ} \mathrm{C}$ but with a $70 \% \mathrm{RH}$.

Despite the low number of aphids killed and progeny produced by $A$. matricariae in our experiment, the interest of both species for natural regulation of $A$. gossypii has to be considered. $A$. matricariae has a significant effect on aphids, even if it is less than that of L. testaceipes. Moreover, the short development time of its offspring could have positive consequences on the aphid population dynamics. These results differ from the findings of Van Steenis (1995) who reported a low number of mummies produced by $A$. matricariae on $A$. gossypii. This difference between studies could be explained by the high genetic variability of this species, probably linked to host specialization (Derocles et al. 2016). The parasitoid population used here, based on individuals collected on A. gossypii, is probably more adapted to this host species than the one used by Van Steenis (1995), which came from a commercial rearing unit.

Moreover, both parasitoid species are considered to be generalists. If demonstrated for the local populations encountered in the semi-arid area, this feature could be used to build conservation biological control strategies against $A$. gossypii, by providing additional host resources to 
the parasitoids. For this purpose, the prevalence of each species in the potatoes fields in the studied area has to be measured, as well as their presence on alternative hosts, both on cultivated and wild plants. It will allow targeting aphid species acting as reservoirs for $L$. testaceipes and A. matricariae, building appropriate crop rotations and managing semi natural habitats near the fields to enhance their abundance and efficiency to control $A$. gossypii on potatoes.

The current pest control system in Algeria through all agro-ecosystems is heavily reliant upon the use of synthetic pesticides to kill pests and in the case of potato crops, chemicals are systematically used to control aphids and the moth Phtorimeae opercullela (Zeller, 1873) (Lepidoptera: Gelechiidae) (the other main pest). The first step to favour aphid regulation by parasitoids would be to decrease insecticide use in this agricultural context. For this purpose, farmers may consider integrated chemical control (Dedryver et al. 2010), based on pest population survey rather than on preventive use of insecticides.

\section{Acknowledgements}

The authors are grateful to B Chaubet, E Turpeau and Y Navasse (UMR IGEPP) for insect identity confirmation and to Dennis Webb for improving previous versions of the manuscript.

\section{References}

Adabi ST, Talebi AA, Fathipour Y \& Zamani AA. 2010. Life history and demographic parameters of Aphis fabae (Hemiptera: Aphididae) and its parasitoid, Aphidius matricariae (Hymenoptera: Aphidiidae) on four sugar beet cultivars. Acta Entomologica Serbica 15(1): 61-73.

Bates D, Mächler M, Bolker BM \& Walker SC. 2015. Fitting Linear Mixed-Effects Models Using Ime4, Journal of Statistical Software, published by the Foundation for Open Access Statistics 67(1): [48].

Bueno VP, Sampaio MV, Bruno JCL, Robson FC, Silva J, Rodrigues SMM \& Carnevale AB. 2006. Evaluation of two aphid parasitoids as candidates for biocontrol of aphid pests in protected cultivation in Brazil. Integrated Control in Protected Crops, Mediterranean Climate. IOBC/wprs Bulletin 29(4): 175-180.

Carnevale AB, Bueno VHP \& Sampaio MV. 2003. Parasitism and Development of Lysiphlebus testaceipes (Cresson) (Hymenoptera: Aphidiidae) on Aphis gossypii Glover and Myzus persicae (Sulzer) (Hemiptera: Aphididae). Neotropical Entomology 32(2): 293-297.
Chaouche TS \& Laamari M. 2015. Aphid parasitoid species (Hymenoptera: Braconidae: Aphidiinae) and their associations in Biskra province, Algeria. Journal of Entomology and Zoology Studies 3(2): 179-184.

Colinet H, Salin C, Boivin G \& Hance TH. 2005. Host age and fitness-related traits in a koinobiont aphid parasitoid. Ecological Entomology 30: 473-479.

Costa A \& Stary P. 1988. Lysiphlebus testaceipes, an introduced aphid parasitoid in Portugal (Hym.: Aphidiidae). Entomophaga 33(4): 403-412.

Dedryver CA, Le Ralec A \& Fabre F. 2010. The conflicting relationships between aphids and men: A review of aphid damage and control strategies. Comptes Rendus Biologies 333: 539-553.

Derocles SAP, Plantegenest M, Rasplus JY, Marie A, Evans D, Lunt D \& Le Ralec A. 2016. Are generalist Aphidiinae (Hym. Braconidae) mostly cryptic species complexes? Systematic Entomology (41): 379-391.

Ferrari J, Müller CB, Kraaijevel, A \& Godfray HCJ. 2001. Clonal variation and covariation in aphid resistance to parasitoids and a pathogen. Evolution 55(9): 1805-1814.

Fuller SJ, Chavigny P, Lapchin L \& Vanlerberghe-Masutti F. 1999. Variation in clonal diversity in glasshouse infestations of the aphid, Aphis gossypii Glover in southern France. Moleculer ecology 8(11): 1867-1877.

Korner-Nievergelt F, Roth T, Von Felten S, Guélat J, Almasi B \& Korner-Nievergelt P. 2015. Bayesian data analysis in ecology using linear models with $R$, BUGS, and Stan. Oxford: Elsevier Academic Press.

Laamari $M$, Chaouche TS, Benferhat $S$, Abbès SB, Merouani H, Ghodbane S, Khenissa N \& Stary P. 2011. Interactions tri-trophiques: plante-puceron-hyménoptère parasitoïde observée en milieux naturels et cultivés de l'Est algérien. Entomologie faunistique 63(3): 115-120.

Leclant F \& Deguine JP. 1994. Aphids (Hemiptera: Aphididae), In Insect Pests of Cotton (Matthews G \& Tunstall JP, eds.). Wallingford: CAB International, pp. 285-323.

LeHouerou H N, Claudin J \& Pouget M. 1977. Etude bioclimatique des steppes algériennes, Bulletin de la Société d'histoire naturelle de l'Afrique du nord 68(34): 33-74.

MADRP. 2018. Statistiques agricoles. Ministère de l'Agriculture du Développement Rural et de la Pèche. Available at http://www.http://madrp.gov.dz (Accesed on 1-V-2019).

Medri C. 2014. Contribution à l'inventaire des pucerons et de leurs ennemis naturels sur culture de pomme de terre (Solanum tuberosum L.) dans la région d'Ain Oussara (Djelfa); Test de luttebiologique. Master en Biosystématique et Ecologie des Arthropodes Terrestres. Université Ziane Achour, Djelfa, Algérie, 71.

Mitrovic M, Petrovic A, Kavallieratos NG, Stary P, Petrovic-Obradovic O, Tomanovic Z, \& Vorburger C. 2013. Geographic structure with no evidence for host-associated lineages in European populations of Lysiphlebus testaceipes, an introduced biological control agent. Biological Control 66 (2013): 150-158.

Nazari Y, Zamani AA, Masoumi SM, Rakhshani E, 
Petrović-Obradović O, Tomanović S, Starý P, \& Tomanović Z. 2012. Diversity and host associations of aphid parasitoids (Hymenoptera: Braconidae: Aphidiinae) in the farmlands of western Iran. Acta Entomologica, Musei Nationalis Pragae 52(2): 559584.

Outreman Y, Le Ralec A, Plantegenest M, Chaubet B \& Pierre JS. 2001a. Superparasitism limitation in an aphid parasitoid: cornicle secretion avoidance and host discrimination ability. Journal of Insect Physiology (47): 339 - 348.

Outreman Y, Le Ralec A, Wajnberg E \& Pierre JS. 2001b. Can imperfect host discrimination explain partial patch exploitation inparasitoids? Ecological Entomology (26): 271 - 280.

Powell W \& Pell JK. 2007. Biological control. In Aphids as Crop Pests. (van Emden HF \& Harrington E, eds). London: CABI Publishing, pp. 469-513.

Rodrigues SM \& Bueno VHP. 2001. Parasitism rates of Lysiphlebus testaceipes (Cresson) (Hym.: Aphidiidae) on Schizaphis graminum (Rond.) and Aphis gossypii Glover (Hem.: Aphididae) Biological Control. Neotropical Entomology 30(4): 625-629.

Romo CM \& Tylianakis JM. 2013. Elevated Temperature and Drought Interact to Reduce Parasitoid Effectiveness in Suppressing Hosts. PLoSONE 8(3): [09].

Saguez J, Giordanengo P \& Vincent C. 2013. Aphids as Major Potato Pests In Insect pests of potato (Alyokhin A, Vincent C \& Giordanengo P, eds.). Amsterdam: Elsevier, pp. 31-63.

Sampaio MV, Bueno VHP, Soglia MCM, De Conti BF \& Rodrigues SMM. 2006. Larval competition between Aphidius colemani and Lysiphlebus testaceipes after multiparasitism of the host Aphis gossypii. Bulletin of Insectology 59(2): 147-151.

Sellami EL, Delvare G \& Chermiti B. 2013. Parasitoids and hyperparasites of citrus aphids in northern east of Tunisia (Cap Bon). Integrated Control in Citrus Fruit Crops IOBC-WPRS Bulletin (95): 131-139.

Silva RJD, Bueno VHP, Silva DB \& Sampaio MV. 2008. Tabela de vida de fertilidade de Lysiphlebus testaceipes (Cresson) (Hymenoptera, Braconidae, Aphidiinae) em Rhopalosiphum maidis (Fitch) e Aphis gossypii Glover (Hemiptera, Aphididae). Revista Brasileira de Entomologia 52(1): 124-130.

Slininger PJ, Behle RW, Jackson MA \& Schisler DA. 2003. Discovery and Development of Biological Agents to Control Crop Pests. Neotropical Entomology 32(2): 183-195.

Soglia MCM, Bueno VHP, Sampaio MV, Rodrigues SMM \& Ledo CAS. 2006. Development and Parasitism of Lysiphlebus testaceipes (Cresson) and Aphidius colemani Viereck (Hymenoptera: Braconidae) on Aphis gossypii Glover (Hemiptera: Aphididae) on Two Chrysanthemum Cultivars. Neotropical Entomology 35(3): 364-370.

Stary P, Lumbierres B, \& Pons X. 2004. Opportunistic changes in the host range of Lysiphlebus testaceipes (Cr.), an exotic aphid parasitoid expanding in the Iberian Peninsula. Journal of Pest Science (77): 139-144.

Talebi AA, Zamani AA, Fathipour Y, Baniameri V, Kheradmand $K$ \& Haghani M. 2006. Host stage preference by Aphidius colemani and Aphidius matricariae (Hymenoptera: Aphidiidae) as parasitoids of Aphis gossypii (Hemiptera: Aphididae) on greenhouse cucumber. IOBC/WPRS Bulletin 29(4): 181-185.

Tepa-Yotto GT, Hofsvang T, Godonou I, Tchibozo I \& Saether MG. 2013. Host instar suitability of Aphis gossypii (Hemiptera: Aphididae) for Lysiphlebus testaceipes (Hymenoptera: Braconidae) and parasitism effect on aphid life table. The Japanese Society of Applied Entomology and Zoology (48):447-453.

Van Steenis MJ. 1995. Evaluation of four aphidiine parasitoids for biological control of Aphis gossypii. Entomologia Experimentaliset Applicata (75): 151-157.

Woodford JAT \& Gordon CS. 2008. New approaches for restricting spread of potato leaf roll virus by different methods of eradicating infected plants from potato crops. Annals of Applied Biology 477-487.

Yahiaoui SR. 2014. Contribution à l'inventaire des pucerons et de leurs ennemis naturels sur culture de pomme de terre (Solanum tuberosum L.) dans la région de Dar Chioukh- Djelfa- Test de luttebiologique. Djelfa, Algérie: Université Ziane Achour. Master en Biosystématique et Ecologie des Arthropodes Terrestres.

Zamani AA Haghani M \& Kheradm K. 2012. Effect of temperature on reproductive parameters of Aphidius colemani and Aphidius matricariae (Hymenoptera: Braconidae) on Aphis gossypii (Hemiptera: Aphididae) in laboratory conditions. Journal of Crop Protection 1(1): 35-40.

Zamani AA, Talebi AA, Fathipour Y \& Baniameri V. 2006. Temperature-dependent functional response of two aphid parasitoids, Aphidius colemani and Aphidius matricariae (Hymenoptera: Aphidiidae), on the cotton aphid. Journal of Pest Science (79): 183-188.

Zamani AA, Talebi AA, Fathipour Y \& Baniameri V. 2007. Effect of temperature on life history of Aphidius colemani and Aphidius matricariae (Hymenoptera: Braconidae), two parasitoids of Aphis gossypii and Myzus persicae (Homoptera: Aphididae). Environmental Entomology 36(2): 263-271. 